\title{
Black Rising: An Editorial Note on the Increasing Popularity of a US American Racial Ethnonym
}

\author{
I. M. NICK
}

Germanic Society for Forensic Linguistics, Germany

In historic protests sparked by the wrongful deaths of US civilians, demonstrators have taken to the streets in record numbers demanding justice and an end to institutionalized racism. US media coverage of this movement has frequently utilized the racial ethnonym Black as opposed to African (-) American. As this note discusses, this choice in nomenclature may not only be due to the increasing prominence of the Black Lives Matter Movement. It may also be indicative of earlier, large-scale shifts in autonymy. This note presents some of the demographic, linguistic, and sociopolitical factors that may well have played a role in the rising use of Black as both an ethnoracial and political identifier.

KEYWORDS ethnonym, race, USA, anthroponym, US Census, Civil Rights, Black Lives Matter

On March I3, 2020, at approximately I am in the morning, the Louisville Metro Police Department (LMPD) raided a Kentucky private residence after receiving information that a drug-tracking ring was using the apartment to store narcotics. As the officers would later discover, the information they had received was wrong. Instead of a clandestine drug den, the officers entered the home of Kenneth Walker and his girlfriend, Emergency Medical Technician, Breonna Taylor.

Although there is ongoing dispute over what exactly transpired once the police entered the premises, forensic evidence recovered at the scene confirms that officers fired more than 20 shots into the apartment. Ms. Taylor, who was shot at least eight times, died in her home as a direct result of her injuries. Nevertheless, on the official incident report written by the LMPD, the responding officers indicated that Ms. Taylor had received no injuries during the operation. The Taylor family has since filed a wrongful death lawsuit stating that the 
LMPD's actions were "executed willfully and with the intent to harm" and constituted a violation of Ms. Taylor's statutory and constitutional rights (Oppel and Taylor 2019). In response to the public uproar over the killing of the award-winning EMT, government authorities vowed to introduce institutional changes.

Almost two months later, the world watched in horror as North Carolina native, George Perry Floyd, cried for help while dying underneath the knees of Minnesota police officers. According to the autopsy conducted by New York City's Chief Medical Examiner, Dr. Michael Baden, the cause of Mr. Floyd's death was asphyxiation from sustained compression of the neck and back which resulted in a lethal interruption of blood and oxygen flow (Reyes, Hughes, and Emmert 2020). In protest against these and other killings, demonstrators around the United States and abroad have taken to the streets. From Berlin, Germany to Sydney, Australia, activists have come together to demand an end to not only the excessive use of force by law enforcement, but also the institutionalized racism which has historically allowed such abuses of power to take place, with little or no punishment for the perpetrators.

US coverage of these protests has dominated the national media with reports detailing the unfolding events from every imaginable angle. Interestingly, even a cursory review of this news coverage reveals a significant onomastic shift: a resurgence in the use of the racial ethnonym Black as compared to the once ubiquitous term African American. Below are just a few sample headlines taken from leading US news media outlets since the killing of Breonna Taylor and George Floyd (Table I):

TABLE 1

HEADLINES FEATURING RACIAL ETHNONYMS FOR US RESIDENTS OF AFRICAN DESCENT FROM MAJOR MEDIA OUTLETS BETWEEN MAY 25 AND JUNE 17, 2020.

\begin{tabular}{|c|c|c|c|}
\hline & Publication Date & News Agency & Headline \\
\hline 1 & May 27,2020 & The New Yorker & $\begin{array}{l}\text { The Multiple Unfolding Crises for African- } \\
\text { Americans in Minneapolis }\end{array}$ \\
\hline 2 & May 29,2020 & Star Tribune & $\begin{array}{l}\text { Crowd protests white mayor's words about } \\
\text { black man's death }\end{array}$ \\
\hline 3 & May 31, 2020 & New York Times & $\begin{array}{l}\text { Black Americans Have Message for } \\
\text { Democrats: Not Being Trump Is } \\
\text { Not Enough }\end{array}$ \\
\hline 4 & June 1,2020 & Rolling Stone Magazine & $\begin{array}{l}\text { American Plague: Racism, our untreated } \\
\text { pre-existing condition, is killing both } \\
\text { black people and the nation itself }\end{array}$ \\
\hline 5 & June 13,2020 & Time Magazine & $\begin{array}{l}\text { Two Black Trans Women Were Killed in the } \\
\text { U.S. in the Past Week as Trump Revokes } \\
\text { Discrimination Protections for } \\
\text { Trans People }\end{array}$ \\
\hline 6 & June 15,2020 & Washington Post & $\begin{array}{l}\text { Former Atlanta police chief walked with } \\
\text { protestors to Demand Change. She } \\
\text { resigned after an officer fatally shot a } \\
\text { black man }\end{array}$ \\
\hline
\end{tabular}


TABLE 1

(CONTINUED).

\begin{tabular}{|c|c|c|c|}
\hline & Publication Date & News Agency & Headline \\
\hline 7 & June 16,2020 & Forbes & $\begin{array}{l}\text { Dear White People: Here Are } 5 \\
\text { Uncomfortable Truths Black Colleagues } \\
\text { Need You to Know }\end{array}$ \\
\hline 8 & June 16,2020 & Chicago Tribune & $\begin{array}{l}\text { Juneteenth honors the day all African } \\
\text { Americans were freed from slavery: } \\
\text { Here's how you can join the celebration }\end{array}$ \\
\hline 9 & June 16,2020 & Wall Street Journal & $\begin{array}{l}\text { Black Officers Say Discrimination Abounds, } \\
\text { Complicating Reform Efforts }\end{array}$ \\
\hline 10 & June 17,2020 & USA Today & $\begin{array}{l}\text { Aunt Jemima to change name, remove } \\
\text { image of Black woman }\end{array}$ \\
\hline 11 & June 17,2020 & The Seattle Times & $\begin{array}{l}\text { Atlanta awaits decision on charges in black } \\
\text { man's killing }\end{array}$ \\
\hline 12 & June 17,2020 & Los Angeles Times & $\begin{array}{l}\text { Two Black Men hanging from trees in } \\
\text { Southern California? Leave no stone } \\
\text { unturned investigating }\end{array}$ \\
\hline 13 & June 17,2020 & Boston Globe & $\begin{array}{l}\text { Commissioner concludes no racial profiling, } \\
\text { but questions search of car containing } \\
\text { Black firefighter }\end{array}$ \\
\hline 14 & June 17,2020 & Fox News & $\begin{array}{l}\text { Tennessee deputy thanks } 2 \text { black women } \\
\text { for buying him breakfast at Cracker } \\
\text { Barrel: 'BLM but so does yours!' }\end{array}$ \\
\hline 15 & June 17,2020 & CNN & $\begin{array}{l}\text { New video shows Black teens handcuffed } \\
\text { for jaywalking }\end{array}$ \\
\hline
\end{tabular}

In such incendiary times, the editorial decision to use Black over African American was by no means an accident. In at least some of the cases shown above, this publication choice may have been made in solidarity with the slogan used by so many protestors: "Black Lives Matters!"

This rallying cry is also the name of one of the most vocal US civil rights organizations of the $2 \mathrm{I}^{\text {st }}$ century, "Black Lives Matters" (BLM). The BLM got its official start in 2013 after the acquittal of the man accused of murdering Trayvon Martin, a I7-year-old unarmed African American teenager. Since its inception, one of the primary goals of what has become an international movement is "to eradicate white supremacy" (BlackLivesMatter.com 2020). The use of the racial ethnonym Black not only underscores the organization's diametrical opposition to White Power movements. It also expresses their commitment to empowering Black communities everywhere-in much the same way that the Black Power Movement sought to do in the I96os. Without a doubt, the public revival of the term Black is related to the rising popularity and prominence of the BLM. However, the re-emergence of this term is by no means solely due to this organization's prominence. In fact, it is likely that the Movement's decision to use the racial ethnonym Black instead of other nomenclature like African(American ${ }^{\mathrm{I}}$, Afro-American, and Black American reflected a pre-existing increase in the usage of Black.

From the perspective of historical linguistics, the re-birth of Black is not at all unusual. Indeed, over the course of US history, the names which have been used 
to label people of African descent have risen and fallen, in a cyclical manner, regularly replacing and displacing one another (Laversuch 2005). Such lexicalsemantic developments have also been witnessed in other semantic domains aside from RACE. For example, much has been written about the more or less successful linguistic re-appropriation of anthroponyms previously used as terms of disparagement for the LGBTQIA community (e.g. dyke, gay, flamer, queer, and queen) (Zwicky I997; Cameron I995). The sociopolitical importance of such linguistic reclamation is described by Alexander Cheves (2020), a reporter for the Advocate:

Many ask in frustration, 'Who cares?' What's in a name?' Names matter. Words are important. Language is fluid, confusing, and evolving. It requires mercy and patience, narrative and explanation. Most of all, it requires listening. How many times have words been used to rob us of power? By using them differently, we take power back (para 4).

Alongside the LGBTQIA community, other intersecting minorities have also successfully harvested the power of reclaiming onomastic ownership. Within the US, such strategic semantic inversion has long played a role in the periodic resurrection of racial ethnonyms used for US American residents of African descent (Dundes 1973). The resulting changes in preferred terminology are far from fickle or frivolous flights of fashion. Rather they are reflective of groundbreaking underlying demographic shifts.

Over the past two decades, for example, the internal composition of that segment of the US population that self-identifies with the government classification African AMERICAN OR Black has undergone significant change. Most notably, there has been a dramatic increase in the proportion of those who are foreignborn. According to the PEW Research Center, since the year 2000, "the number of black immigrants living in the country has risen $7 \mathrm{I} \%$ " (Anderson and Lopez 20I 8, para 2). Today, nearly I०\% of US residents with this classification were born outside of the United States. This immigrant sub-population has brought with it different notions of ethnoracial classifications, many of which are at complete odds with the system historically used in the United States. Palpable shifts have consequently resulted in the overall perception of, comfort with, and preferences in the self-identifiers African American and Black. Considerable research has determined, for example, that immigrants from Africa and Latin America often feel ill at ease with African American as an autonym (Anderson and Lopez 2018; Jones 20I3; Taylor et al. 20I2). The frequent complaint is that African American is simultaneously too amorphous. Africa, they remind, is an entire continent with many different cultures, traditions, nationalities, and identities. At the same time, these critics also point out that African American is far too restrictive in that it negates the existence of dark-skin people from other continents. Consequently, many foreign-born immigrants feel the term Black is much more accurate and inclusive. 
The cumulative influence of these differing onomastic sensibilities is not merely a function of the numerical size of this sub-group. As data gathered from the US Bureau of Census has repeatedly shown, foreign-born members of the classification African AMERICAN OR BLACK tend to enjoy relatively high levels of socio-economic affluence and academic achievement (Nielsen Research 2015). ${ }^{2}$ An excellent case in point are US Americans with Nigerian heritage. According to the Bureau's American Community Survey, in 2018, an impressive 59\% of this sub-population had achieved a bachelor's degree or higher. This percentage is roughly twice as high as that recorded for the overall US population (US Bureau of Census 20I8). Similarly positive statistics have been obtained for other immigrant communities identified as African AMERICAN OR BlaCK. ${ }^{3}$ This collective affluence and education means these sub-communities have great power to elicit onomastic change within the popular discourse. Nation-wide diachronic shifts evident in the preference Black over African American may be a partial reflection of the changing way many US residents view themselves in relation to Others.

Of course, for those who are unaware of or not completely privy to these developments, the resulting lexical-semantic shifts may feel more than a bit disconcerting. In the past, these onomastic changes have been met with bewilderment, consternation, ridicule, and derision. Precisely this combination of irritation and condescension was expressed in a letter written to syndicated newspaper advice columnist, Ann Landers, in I989. In response to Landers's support of the switch from Black to African American, an indignant reader from Valparaiso, Indiana wrote: "Why don't the blacks make up their minds? The whole subject is becoming tiresome. They chose black because they did not like Negro." ("The Hartford Courant" I989, H6). Aside from the modern irritation of the lower-case " $b$ " and the direct article placed in front of the racial ethnonym - a formation which is reminiscent of descriptions used for animal species (i.e. the monkeys, the gorillas, *'the blacks') - the reader's suggestion that a group of people with nearly 200 , 000 , 000 members would have a single opinion about anything is simply ludicrous. Even IF such a consensus could be reached, the idea that this opinion would be invariant for all times goes counter to everything we know about the fluid and dynamic nature of language and identity. Nevertheless, it is also appreciated that people who do not identify as AfricAn AMERICAN OR BLACK may well experience a profound sense of insecurity when seeking to find a group name that is up-to-date, accurate, and sensitive.

Given the significance of ethnoracial identity and identification in the US, it comes as no surprise that this insecurity is not limited to private interpersonal communication, but also affects public official discourse. With the goal of identifying the ethnoracial nomenclature deemed acceptable by a maximal number of people while minimizing the risk of causing offense, the naming preferences of the US population are regularly surveyed by private and public agencies. For example, in a nation-wide survey conducted by the US Department of Labor, Black was the most preferred racial ethnonym by respondents $(44.2 \%)$, followed by African 
American which was favored by $28 . \mathrm{\%} \%$. Only 9.1\% of the respondents reported that they had no preference (US Bureau of Census I996, 8). Interestingly, slightly different findings have been reported by social scientists and survey research firms in the private sector. Since the I990s', for example, many non-governmental nationally representative surveys have revealed that more than half of the respondents found African American or Black to be equally acceptable autonyms and they had no preference one way or the other (e.g. Jones 2013; Newport 2007; Sigelman, Tuch, and Martin 2005). ${ }^{4}$ However, amongst respondents who did have a preference, an important diachronic trend emerged. Figure I below demonstrates

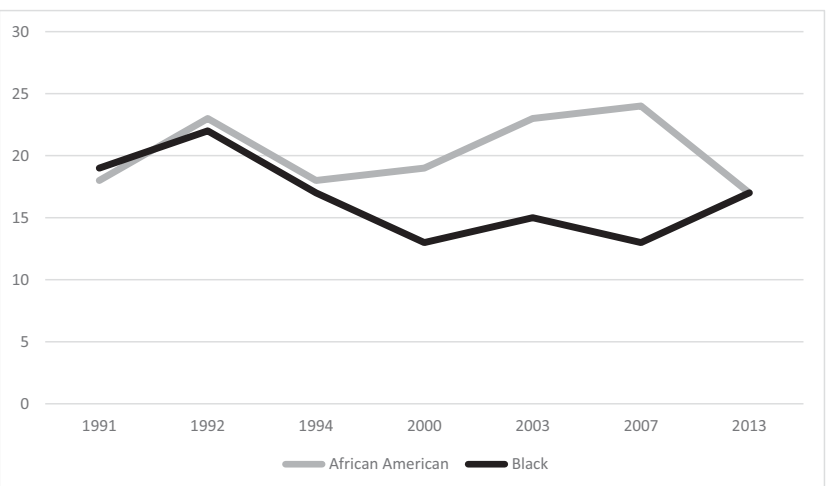

FIGURE 1. US residents' changing preferences in the use of African American and Black as an autonym as documented by Gallup.

this development as it appeared in data collected by Gallup over that past two decades. As can be seen in the chart above, for the past twenty years, African American has been the self-identifier of choice amongst those who voiced a preference for an ethnoracial autonym in the Gallup surveys. However, since approximately 2007 , the in-group popularity of this endonym has been in sharp decline, while Black has dramatically risen. ${ }^{5}$

Despite this internal trend amongst US American residents classified as AFrican AMERICAN OR Black, there is much anecdotal and empirical evidence that this development may not have taken hold outside of this demographic cluster. For example, in social psychological research conducted in 2015 with US Americans who self-identify as WHITE, it was found that African American was still overwhelmingly preferred over Black (Hall, Phillips, and Townsend 2015). This was not the only significant finding of this study, however. It was also determined that among White study participants, Black was also associated with a lower socioeconomic status and level of educational attainment than African American. In all likelihood, today's Civil Rights demonstrators are aware of the negative perceptions many members of the power elite (un)consciously associate with the name Black. However, instead of allowing those stereotypes to dictate 
their onomastic choices, they have elected to strategically utilize them, in much the same way as leaders of the Black Power Movement did in the I96os. During that cultural revolution, Black was commonly perceived as being "starkly confrontational and militant" (Martin I99I, 90). Civil Rights leaders then effectively used that image to encourage their followers to not simply "accept but embrace therefore undesirable racial qualities" (Martin I99I, 90).

Today, a little over a half a century after the assassination of Reverend Martin Luther King and the recent killings of Ahmaud Arbery, Atatiana Jefferson, Botham Jean, Breonna Taylor, Eric Garner, George Floyd, Shelly Frey, Freddie Gray, Miriam Carey, Sandra Bland, Tamir Rice, Tanisha Anderson, Trayvon Martin and so many others ${ }^{6}$, millennials have once again taken up the name Black to re-imbue it with a new sense of uncompromising unity. For despite the growing diversity of this sub-population, in a nation where your life may be at risk by simply sitting in your apartment after a hard day's work, attending a prayer circle at a local church, going for a quick morning jog around the block, or watching birds in a neighborhood park, the fact that you come from Jamaica or Cuba, Detroit or Tulsa, possess a university degree, or have a job essential to the welfare of your community makes little difference when the person standing across from you is holding a weapon and you have dark skin.

This truth of this statement is glaringly reflected in the nation's shocking statistics. FBI data on US hate-crimes reported in 2018 indicate, for example, that of the 5, I 55 cases recorded by law enforcement, 47.I \% of the victims were targeted by offenders with anti-Black or anti-African American ideology (FBI 2019). From 20I3 to 20I7, the US Department of Health and Human Services (2019) determined that White patients in the US received a higher quality health care than $27 \%$ of Asians, $35 \%$ of Latinxs, and $40 \%$ of patients who had one of the following Census classifications: Native Hawailan/Pacific Islanders, Alaska Natives/American Indian, or African American/Black (2019). The effect of such disparities in the quality of and access to healthcare has become all too clear in the wake of the COVID-I9 outbreak. In recognition of these and other injustices, for many, the decision to use the autonym Black is more than an expression of personal taste. It is a public declaration of unity with other peoples of color who face similar discrimination.

This choice does not mean, however, that the term African American has suddenly, once again, become obsolete. Instead, what we may well be entering is a period in which it and Black are being actively but differently used-their selection situationally depending upon people's needs, goals, alliances, and oppositions. In one context, a language-user may feel that African American is most fitting; and in other situations, that very same person may perceive Black to be the most appropriate term of self-reference. Whether one or both of these two racial ethnonyms will still be a part of US public discourse in a decade's time is nearly impossible to say. There are simply too many known and unknown variables that impact upon onomastic trends to make an accurate prediction. 
Nevertheless, despite all that unpredictability, there is still one constant: the names we chose to call ourselves and others ... matter.

\section{Notes}

I. For many years, there was a great deal of discussion in the popular media and academia over whether or not to hyphenate African American. Similarly heated debates were waged over whether one or all racial ethnonyms should be capitalized wordinitially; and if so, under what circumstances, be they grammatical or political. For more on these points, see: (Allen I988; Baugh I99I; Nuessel I992).

2. Statistics gathered via the Census's American Community Survey indicated that $50.3 \%$ of foreign-born US residents who classified themselves as AFrICAN-AMERICAN OR BLACK came from "Latin America" (US Bureau of Census 20I8).

3. According to the US Census, among US residents who self-identified as AFrICAN AMERICAN OR BLACK but were born in Ethiopia, Ghana, or Kenya, an impressive $3 \mathrm{I} \%, 37 \%$, and $47 \%$ had respectively achieved a bachelor degree or higher (Anderson and Lopez 20I8).

4. A similar result was obtained for residents asked to state whether they preferred
Hispanic or Latino as an autonym. In a 2013 nationally representative Gallup poll, ı०\% of respondents selected Latino, I9\% Hispanic, and $70 \%$ indicated that it did not matter to them which of the two was used. (Jones 20I3). For more, see also Taylor et al. (20I2).

5. What is particularly interesting here is that there does not seem to have been an equivalent resurgence of popularity in the autonym Black American, where a color term and nationality marker are united in a single identifier. To a certain extent, popular aversion of this term may be endemic of the pervasive sentiment that institutionalized racism has disallowed many people from being both Black and US American.

6. Readers are encouraged to learn more about the \#SayHerName project, a campaign devoted to calling attention to Black women victims of police brutality in the United States. See (https://aapf.org/ sayhernamereport/)

\section{Bibliography}

Allen, Irving. 1988. "Sly Slurs: Mispronunciation and Decapitalization of Group Names." Names 36, no.3-4: 217-224.

Anderson, Monica, and Gustavo Lopez. 201 8. "Key Facts About Black Immigrants in the United States." Pew Research Center. Accessed June I9, 2020. www.pewresearch.org.

Baugh, John. I99I. "The Politicization of Changing Terms of Self-Reference among American Slave Descendants." American Speech 66, no.2: I33-I46.

BlackLivesMatter.com. 2020. “About.” Accessed June I, 2020. https://blacklivesmatter.com/.

Boston Globe. 2020, June 17. "Commissioner Concludes No Racial Profiling, But Questions Search of Car Containing Black Firefighter.” By Edward Fitzpatrick. Accessed June 17, 2020. https://www.bostonglobe.com/2020/06/I 6/metro/commissioner-concludes-no-racial-profiling-questions-search-car-containing-black-firefighter/.

Cameron, Deborah. I995. Verbal Hygiene. New York: Routledge.

Cheves, Alexander. 2020. "2I Words the Queer Community Has Reclaimed (and Some We Haven't)." Advocate. Accessed June 20, 2020. https://www.advocate.com/arts-entertainment/20I7/8/02/2I-wordsqueer-community-has-reclaimed-and-some-we-havent\#media-gallery-media- I.

Chicago Tribune. 2020, June 16. "Juneteenth Honors the Day all African Americans were Freed from Slavery: Here's How You Can Join the Celebration.” By Christen Johnson. Accessed June I7, 2020. https://www.chicagotribune.com/lifestyles/ct-life-juneteenth-activities-chicago-tt-o6 I 5202006 I 6-723qllg5n 5 gtjpitadpwnvalvi-story.html.

CNN.com. 2020, June 17. "New Video Shows Black Teens Handcuffed for Jaywalking." CNN. Accessed June I7, 2020. https:/edition.cnn.com/videos/us/2020/06/I I/tulsa-police-arrest-black-teen-for-jaywalking-vpx.cnn. 
Dundes, Alan. 1973. Mother Wit from the Laughing Barrel. Jackson, Mississippi: University Press of Mississippi.

FBI. 20I9. "2018 Hate Crime Statistics.” Accessed June I9, 2020. https://ucr.fbi.gov/hate-crime/2018/ topic-pages/victims.

Forbes. 2020, June I6. "Dear White People: Here Are 5 Uncomfortable Truths Black Colleagues Need You to Know.” By Dana Brownlee. Accessed June I7, 2020. https://www.forbes.com/sites/danabrownlee/ 2020/06/I 6/dear-white-people-here-are-5-uncomfortable-truths-black-colleagues-need-you-toknow/\#6f7c37 ic624e.

Fox News. 2020, June I7. "Tennessee Deputy Thanks 2 Black Women for Buying him Breakfast at Cracker Barrel: 'BLM but so does yours!.” By Kaylin Jorge. Accessed June I7, 2020. https://www.foxnews.com/ food-drink/tennessee-cracker-barrel-deputy-blm-breakfast.

Hall, Erika, Katherine Phillips, and Sarah S. M. Townsend. 2015. "A Rose by Any Other Name? the Consequences of Subtyping 'African Americans' from 'Blacks." Journal of Experimental Social Psychology 56: I83-I90.

Jones, Jeffrey M. 2013, July 26. “U.S. Blacks, Hispanics Have No Preferences on Group Labels.” Accessed June I6, 2020. https://news.gallup.com/poll/I63706/blacks-hispanics-no-preferences-group-labels.aspx.

Landers, Ann. 1989, April 2. "Racial Term Draws Heat from Readers." The Hartford Courant. Sunday Advice Column. Accessed June 22, 2020. www.newspapers.com.

Laversuch, I. M. 2005. Census and Consensus: A Historical Examination of the US Census Racial Terminology. Used for American Residents of African Ancestry. Berlin: Peter Lang Verlag.

Los Angeles Times. 2020, June 17. "Two Black Men Hanging from Trees in Southern California? Leave No Stone Unturned Investigating.” Accessed June 17, 2020. https:/www.latimes.com/opinion/story/ 2020-06-I $7 /$ palmdale-hanging-black-men.

Martin, B. L. I99I. "From Negro to Black to African-American: The Power of Names and Naming." Political Science Quarterly 106, no.I: 83-107.

New York Times. 2020, May 3I. "Black Americans Have a Message for Democrats: Not Being Trump is Not Enough.” By Astead Herndon. Accessed June 19, 2020. https://www.nytimes.com/issue/todayspaper/2020/06/oI/todays-new-york-times.

Newport, Frank. 2007, September 28. "Black or African American?” Accessed June I, 2020. https://news. gallup.com/poll/288 I6/black-african-american.aspx.

Nielsen Research. 201 5. "Increasingly Affluent, Educated, and Diverse: African-American Consumers: The Untold Story.” Nielsen Report. Accessed June I9, 2020. https:/www.nielsen.com/wp-content/uploads/ sites/3/2019/04/african-american-consumer-untold-story-sept-201 5.pdf.

Nuessel, Frank. I992. The Study of Names: An Introduction to the Principles and Topics. University of Michigan: Greenwood Press.

Oppel, Richard, and Derrick Taylor. 2019, June I9. “Breonna Taylor's Death: What to Know.” The New York Times. Accessed June I9, 2020. https://www.nytimes.com/article/breonna-taylor-police.html.

Reyes, Lorenzo, Trevor Hughes, and Mark Emmert. 2020, June I. "Medical Examiner and Family-commissioned Autopsy Agree: George Floyd's Death was a Homicide.” USA Today. Accessed June I, 2020. https://eu.usatoday.com/story/news/nation/2020/06/oI/george-floyd-independent-autopsy-findings-releasedmonday/5307 I $85002 /$.

Rolling Stone Magazine. 2020, June I. "American Plague: Racism, Our Untreated Pre-existing Condition, is Killing Both Black People and the Nation Itself.” By Jamil Smith, Accessed June I7, 2020. https:// www.rollingstone.com/politics/political-commentary/american-plague-racism-george-floyd-police-brutality-1008387/.

Star Tribune. 2020, May 29. "Crowd Protests White Mayor's Words about Black Man's Death.” Accessed June I7, 2020. https://www.startribune.com/mississippi-mayor-flouts-calls-to-resign-over-floyd-comments/ $570859792 /$.

Sigelman, Lee, Steven Tuck, and Jack Martin. 2005. "What's in a Name? Preference for Black versus African-American.” Public Opinion Quarterly 69, no.3: 429-438.

Taylor, Paul, Mark Lopez, Jessica Martinez, and Gabriel Velasco. 20I 2, April 4. "When Labels Don't Fit: Hispanics and Their Views of Identity." Identity, Pan-Ethnicity and Race. Accessed June I5, 2020. www. pewresearch.org.

The New Yorker. 2020, May 27. "The Multiple Unfolding Crises for African-Americans in Minneapolis." By Isaac Chotiner. Accessed June I7, 2020. https://www.newyorker.com/news/q-and-a/the-multipleunfolding-crises-for-african-americans-in-minneapolisg. 
The Seattle Times. 2020, June I7. “Atlanta Awaits Decision on Charges in Black man's Killing.” By Kate Brumback. Accessed June I7, 2020. https://www.seattletimes.com/nation-world/nation/atlanta-awaitsdecision-on-charges-in-black-mans-killing/.

The Wall Street Journal. 2020, June I6. "Black Officers Say Discrimination Abounds, Complicating Reform Efforts.” By Dan Frosch and Ben Chapman. Accessed June 17, 2020. https://www.wsj.com/ articles/for-black-police-discrimination-abounds-complicating-reform-efforts-I I 592299800.

The Washington Post. 2020, June I5. "Former Atlanta Police Chief Walked with Protestors to Demand Change: She Resigned After an Officer Fatally Shot a Black Man.” By Roberto Klemko. Accessed June I7, 2020. https://www.washingtonpost.com/.

Time Magazine. 2020, June I3. "Two Black Trans Women Were Killed in the US in the Past Week as Trump Revokes Discrimination Protections for Trans People.” By Madeleine Carlisle. Accessed June I7, 2020. https://time.com/5853325/black-trans-women-killed-riah-milton-dominique-remmie-fells-trump/.

US Bureau of Census. I996, April. "Monthly News from the US Bureau of the Census." The Census and You. US Department of Commerce. 3I. no. 4. Accessed June I7, 2020. https://www2.census.gov/library/ publications/I996/census-newsletter/cay-I996-04.pdf.

US Bureau of Census. 20I8. "Selected Population Profile in the United States: African Americans." Accessed June I9, 2020. www.data.census.gov.

US Department of Health and Human Services. 2019. "2018 National Healthcare Quality and Disparities Report.” Accessed June 2I, 2020. https:/www.ahrq.gov/sites/default/files/wysiwyg/research/findings/ nhqrdr/20I 8qdr-final.pdf.

Zwicky, Arnold. I997. “Two Lavender Issues for Linguists.” In Queerly Phrased: Language, Gender, and Sexuality. Edited by Anna Livia and Kira Hall, 2I-35. New York: Oxford University Press.

\section{Notes on contributor}

I. M. Nick holds a BA (Germanics), BSc (Clinical/abnormal Psychology), MA (German Linguistics), MSc (Forensic and Investigative Psychology), as well as a $\mathrm{PhD}$ and the German "Habilitation" (English Linguistics). Her research areas include forensic linguistics, multilingualism, language policy, Holocaust Studies, slavery, and onomastics. She is the President of the Germanic Society for Forensic Linguistics (GSFL) and the immediate Past President of the American Name Society (ANS). She is also the Editor-in-Chief of NAMES.

Correspondence to: Professor Dr. I. M. Nick, Germanic Society for Forensic Linguistics, Germany. Email: mavi.yaz@web.de 